\title{
Colletotrichum karstii causes anthracnose on the orchid Cattleya walkeriana in Brazil
}

\author{
André Luís Silva ${ }^{1} \cdot$ Sara Salcedo-Sarmiento ${ }^{1}$ (D) Paloma Stefany Correa Mansur ${ }^{1} \cdot$ Robert Weingart Barreto $^{1}$
}

Received: 27 April 2021 / Accepted: 14 July 2021 / Published online: 22 July 2021

(c) Australasian Plant Pathology Society Inc. 2021

\begin{abstract}
Colletotrichum karstii is reported, for the first time, causing anthracnose on the native Brazilian orchid Cattleya walkeriana. Identification was confirmed through a combination of morphological and molecular (phylogenetic analysis of the ITS, GAPDH and TUB2 regions) data. Koch's postulates were fulfilled through the inoculation of C. karstii on C. walkeriana.
\end{abstract}

Keywords Fungus $\cdot$ Leaf necrosis $\cdot$ Glomerella $\cdot$ Orchidaceae $\cdot$ Ornamental $\cdot$ Pathogenicity

The Orchidaceae is one of the largest families of flowering plants (Christenhusz and Byng 2016). It includes many species which are commercially cultivated, and orchid cultivation is a very significant industry in Brazil and worldwide (De and Medhi 2015). Some genera are highly demanded by the ornamental plant market or play a key role as sources of commercial hybrids that are broadly cultivated. Cattleya walkeriana is among the best-known Brazilian orchids. It used to have a broad original distribution in Brazil (Barros et al. 2015) but became rare in nature because of habitat destruction and illegal collecting. It is an epiphyte which produces large and showy flowers making it particularly attractive to collectors, commercial growers and breeders (Da Silva and Milaneze-Gutierre 2004). Nevertheless, this interest is not mirrored by research results appearing in the scientific literature, particularly in C. walkeriana pathology. Nothing has been published about fungal diseases of $C$. walkeriana. No fungi are listed on this host in Mendes and Urben (2021) as occurring on this host in Brazil nor in Farr and Rossman (2021) at a world scale. This represents a surprising gap of information for an economically important ornamental species.

In July 2016 a sample of $C$. walkeriana was sent by a commercial orchid grower from Belo Horizonte (state of Minas Gerais, Brazil) for diagnosis at the Clínica de Doenças de Plantas (Departamento de Fitopatologia,

Sara Salcedo-Sarmiento

ssalcedosarmiento@gmail.com

1 Departamento de Fitopatologia, Universidade Federal de Viçosa, Viçosa, MG 36570 - 900, Brazil
Universidade Federal de Viçosa—UFV). Upon preliminary visual examination it was readily recognized that plant leaves were severely attacked by an anthracnose disease. Lesions were circular to elliptic or irregular, 15 to $50 \times 10$ to $30 \mathrm{~mm}$ diam, necrotic areas were sunken and orange mucilagenous spore drops were formed over those areas (Fig. 1b). A representative sample was selected, dried in a plant press and deposited in the local herbarium at UFV (Acc. No VIC44234). Fragments of sporulating lesions were left for $2 \mathrm{~h}$ in a humid chamber in order to soften the spore masses and conidia were transferred to potato dextrose-agar (PDA) plates with a sterile fine pointed needle. Homogeneous pure cultures were formed on those plates after seven daysincubation at $25^{\circ} \mathrm{C}$. A representative isolate was deposited in the local culture collection (Acc. No. COAD2289). For morphological observations, scraped fungal structures from the lesions with a scalpel or hand sections made from the mature lesion with a razor blade were mounted on slides in lactoglycerol. Upon examination under a light microscope (Olympus BX 53, equipped with DIC and an image capture system-Olympus Q-Color $3{ }^{\mathrm{TM}}$ ) and measurement of fungal structures ( $n=30$ for each structure), the following morphology was observed: Appressoria brown, smoothwalled, subglobose, elliptical or clavate $5-15 \times 3-8 \mu \mathrm{m}$ (Fig. 1d). Conidiomata acervular, circular $340-620 \mu \mathrm{m}$ in diam (Fig. 1c). Setae not seen. Conidia hyaline, smoothwalled, aseptate, cylindrical 10-14.5×5-8 $\mu \mathrm{m}$ (Fig. 1e).

Total DNA was extracted from single-spore isolate COAD2289 using Wizard Genomic DNA Purification kit (Promega) by following the manufacturer's instructions. The internal transcribed spacer (ITS) region, and partial 

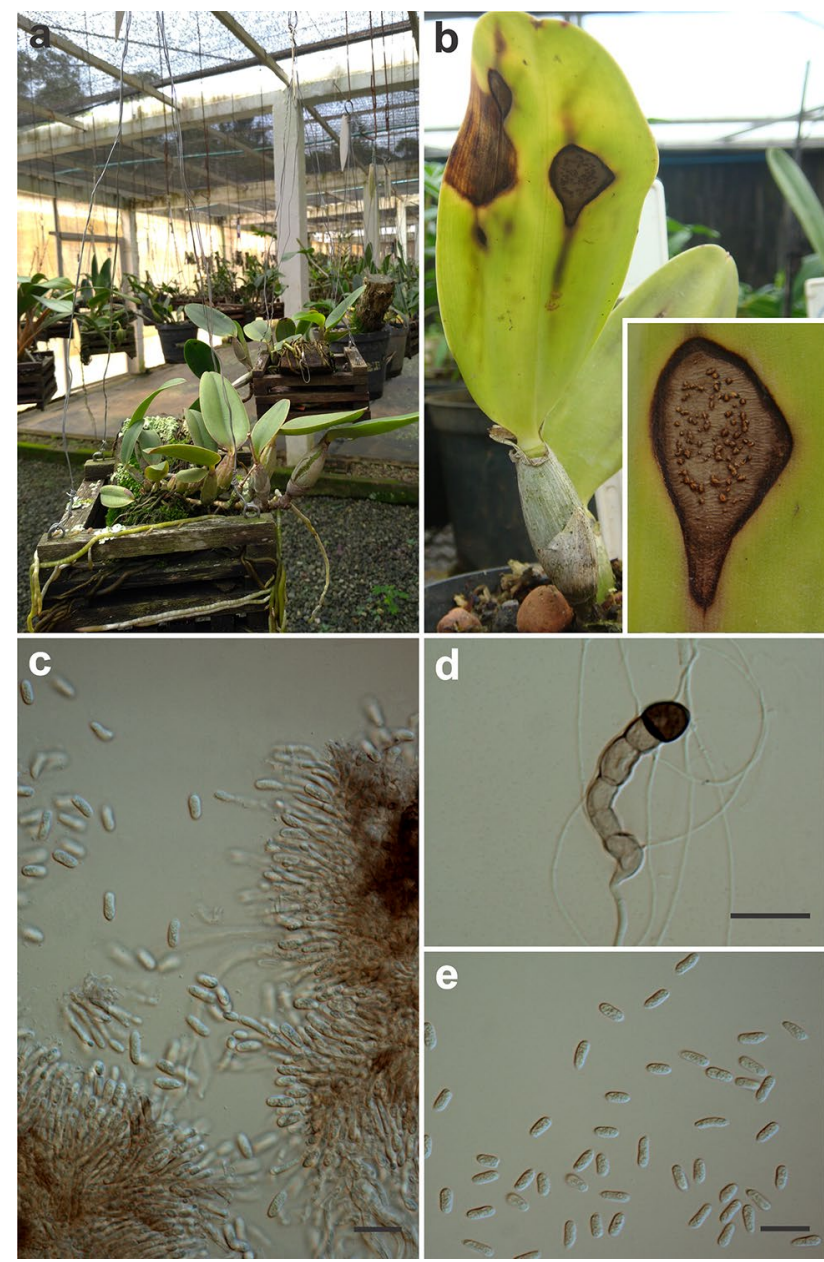

Fig. 1 Colletotrichum karstii on Cattleya walkeriana. C. walkeriana in orchid collection at the Universidade Federal de Viçosa (a). $C$. walkeriana leaf bearing severe anthracnose symptoms with sporulating acervuli of $C$. karstii (b). Squashed mount of acervulus showing conidiophores and conidia (c). Apressoria (d). Conidia (e). Bars $=20 \mu \mathrm{m}$

sequences of glyceraldehyde-3-phosphate dehydrogenase (GAPDH), and $\beta$-tubulin (TUB2) genes were amplified and sequenced with the primer pairs ITS4/ITS5 (White et al. 1990), GDF1/GDR1 (Guerber et al. 2003), T1/Bt2B (O' Donnell and Cigelnik 1997; Glass and Donaldson 1995), respectively. PCR reactions were performed as described in Damm et al. (2012). The DNA sequences were deposited in GenBank (Acc. No.: ITS, MT649669; GAPDH, MW561634 and TUB2, MW561635). The sequences were aligned and a multilocus phylogenetic tree, based on Bayesian inference, for species belonging to the $C$. boninense species complex was constructed. Results of the phylogenetic study (Fig. 2) combined with the morphology data placed COAD2289 into C. karstii.

Pathogenicity of COAD2289 was tested on healthy $C$. walkeriana plants. Three adult plants were used in the study and each leaf was used as an experimental unit. Inoculations were performed on all leaves of two $C$. walkeriana plants. Culture disks were taken from actively growing $(5 \mathrm{~mm}$ diam) 7 days-old colonies of $C$. karstii on PDA and placed centrally on the underside of leaves. At each selected point, prior to inoculation, leaves were superficially bruised with a sterile needle. Leaves of control plants of $C$. walkeriana were treated similarly but received non-colonized, sterile PDA disks. Plants were left in a dew chamber for $48 \mathrm{~h}$ and then placed on a greenhouse bench at $25{ }^{\circ} \mathrm{C}$ and observed daily. Eight to ten days after inoculation typical anthracnose symptoms appeared only at positions of $C$. walkeriana leaves where $C$. karstii disks had been placed, whereas the control leaves remained healthy. Colletotrichum karstii was consistently reisolated from necrotic leaf lesions of Cattleya walkeriana, fulfilling Koch's postulates.

Anthracnose of orchids caused by Colletotrichum spp. is a common disease problem worldwide (Youlian et al. 2011). Until recently, most anthracnose diseases were attributed to Colletotrichum gloeosporioides, including on orchids (McMillan 2011). Nevertheless, this changed dramatically along recent years after a series of molecular reappraisals of the genus Colletotrichum (e. g. Damm et al. 2012). Already under the new taxonomic treatment for the genus, $C$. karstii belonging to the $C$. boninense complex was recognized as among the etiological agents behind orchid anthracnose in China in 2011 on Eria coronaria (Youlian et al. 2011).

Colletotrichum karstii is known to have a broad hostrange spectrum. Over one hundred plant species belonging to numerous families were listed in Farr and Rossman (2021) as hosts, including orchids belonging to the genera Arundina, Calanthe, Eria, Vanda (Youlian et al. 2011), Bletila (Tao et al. 2013), and Phalaenopsis (Jadrane et al. 2012), Nevertheless, all these fungus-host associations represent records from China and the USA. This is the first report of $C$. karstii causing anthracnose on Cattleya walkeriana worldwide. 


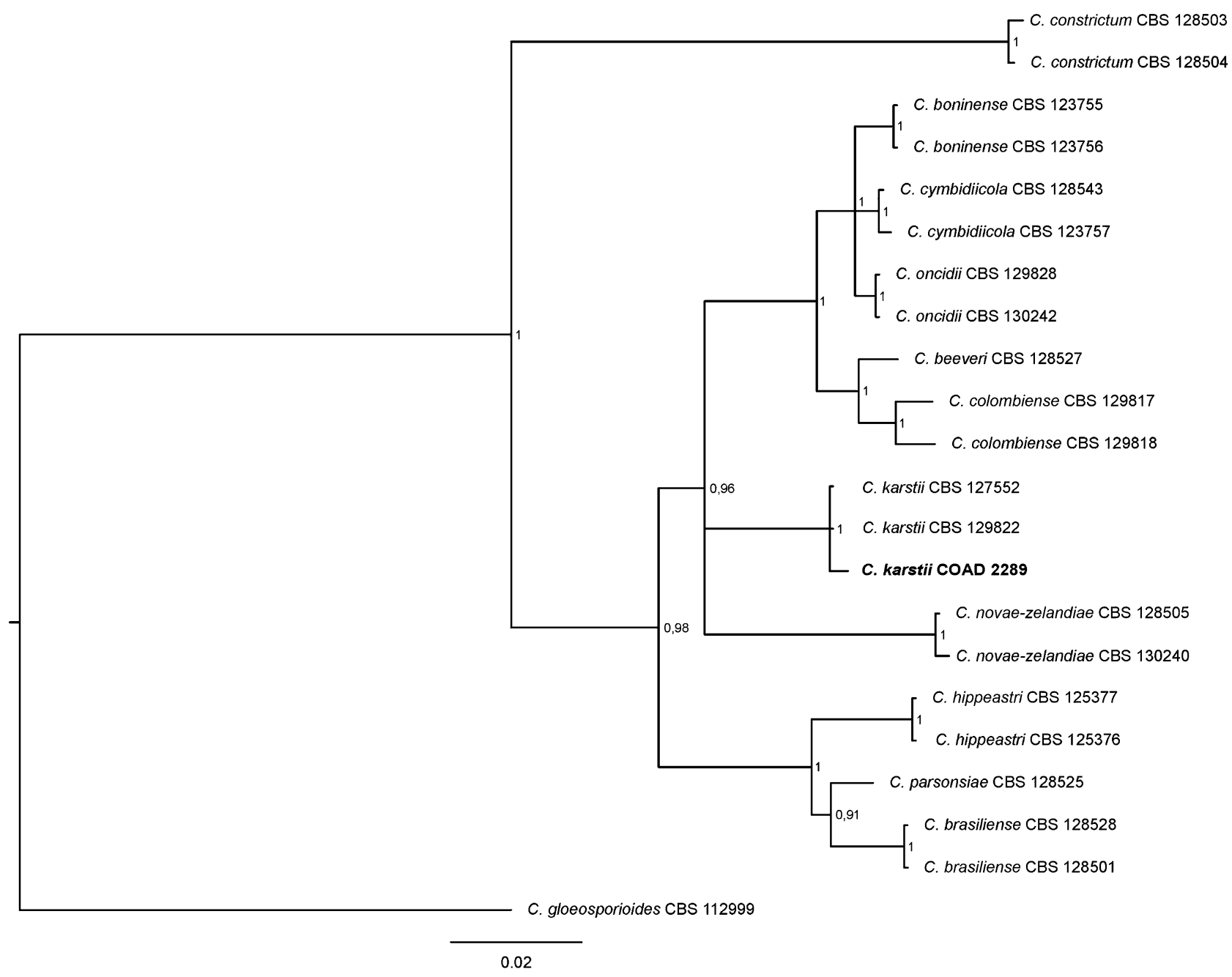

Fig. 2 Bayesian Inference tree of concatenated molecular data (ITS, GAPDH and TUB2) indicating the phylogenetic placement of isolate COAD 2289 from Cattleya walkeriana within the Colletotrichum boninense complex and belonging to Colletotrichum karstii.

\section{References}

Barros F, Vinhos F, Rodrigues VT, Barberena FFVA, Fraga CN, Pessoa EM, Forster W, Menini Neto L, Furtado SG, Nardy C, Azevedo CO, Guimarães LRS (2015) Orchidaceae in Lista de Espécies da Flora do Brasil. Jardim Botânico do Rio de Janeiro. http://floradobrasil.jbrj. gov.br/jabot/floradobrasil/FB31789. Accessed 15 Jan 2021

Christenhusz MJM, Byng JW (2016) The number of known plant species in the world and its annual increase. Phytotaxa 216:201-217

Da Silva CI, Milaneze-Gutierre MA (2004) Caracterização morfoanatômica dos órgãos vegetativos de Cattleya walkeriana Gardner (Orchidaceae). Acta Scientiarum. Biol Sciences, Maringá 26:91-100

Damm U, Cannon PF, Woudenberg JHC, Johnston PR, Weir BS, Tan YP, Shivas RG, Crous PW (2012) The Colletotrichum boninense species complex. Stud Mycol 73:1-36

De LC, Medhi RP (2015) Orchid: A diversified component of farming systems for profitability and livelihood security of small and marginal farmers. J Glob Biosciences 4:1393-1406

Farr DF, Rossman AY (2021) Fungal Databases, U.S. National Fungus Collections, ARS, USDA. Retrieved March 26, 2021, from https://nt.ars-grin.gov/fungaldatabases/
Bootstrap for posterior probability values given at nodes. Tree rooted with Colletotrichum gloeosporioides (CBS 112,999). Isolate from C. walkeriana COAD 2289 shown in bold. The scale bar represents nucleotide substitutions per site

Glass NL, Donaldson G (1995) Development of primer sets designed for use with PCR to amplify conserved genes from filamentous ascomycetes. Appl Environ Microbiol 61:1323-1330

Guerber JC, Liu B, Correll JC, Johnston PR (2003) Characterization of diversity in Colletotrichum acutatum sensu lato by sequence analysis of two gene introns, mtDNA and intron RFLPs, and mating compatibility. Mycologia 95:872-895

Jadrane I, Kornievsky M, Desjardin DE, He ZH, Cai L, Hyde K (2012) First report of flower anthracnose caused by Colletotrichum karstii in white phalaenopsis orchids in the United States. Pl Dis 96:1227

McMillan RTJ (2011) Efficacy of fungicides for control of Colletotrichum gloeosporioides on Dendrobiums. Proc Fla State Hort Soc 124:314-316

Mendes MAS, Urben AF (2021) Fungos relatados em plantas no Brasil, Laboratório de Quarentena Vegetal. Brasília, DF: Embrapa Recursos Genéticos e Biotecnologia. http://pragawall.cenargen.embrapa. br/aiqweb/michtml/fgbanco01.asp. Accessed 19 Mar 2021

O’Donnell K, Cigelnik E (1997) Two divergent intragenomic rDNA ITS2 types within a monophyletic lineage of the fungus Fusarium are nonorthologous. Mol Phylogenet Evol 7:103-116 
Tao G, Liu ZY, Liu F, Gao YH, Cai L (2013) Endophytic Colletotrichum species from Bletilla ochracea (Orchidaceae), with descriptions of seven new species. Fung Diversity 61:139-164

White TJ, Bruns T, Lee S, Taylor J (1990) Amplification and direct sequencing of fungal ribosomal RNA genes for phylogenetics. In: Innis MA, Gelfand DH, Sninsky JJ, WhiteTJ (eds) PCR protocols, a guide to methods and applications. Academic Press, San Diego, pp 315-322

Youlian Y, Cai L, Ziniu Yu Z, Liu Z, Hyde KD (2011) Colletotrichum species on Orchidaceae in southwest China. Cryptog Mycol $32: 229-253$ 